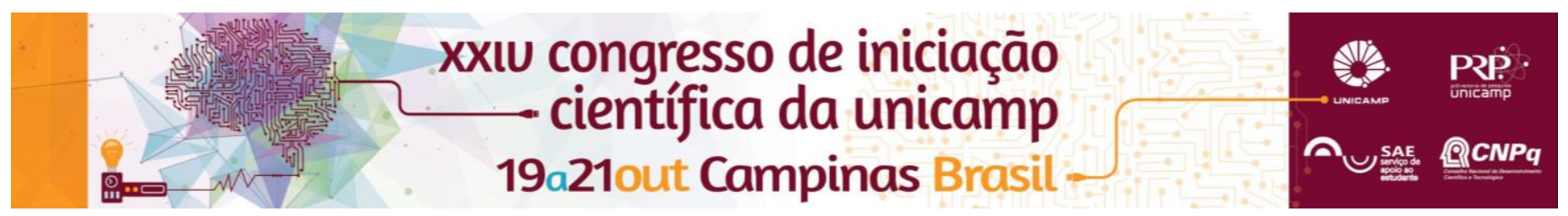

\title{
Desvendando as Folias do Agreste Sergipano em Itabaiana e Lagarto: Um Estudo no eixo CoHabitar com a Fonte do Método BPI
}

\author{
Victória L. Hernandez ${ }^{\star}$ Graziela Rodrigues, Larissa Turtelli.
}

\section{Resumo}

O projeto em questão dedicouse ao aprofundamento da pesquisadora no método BailarinoPesquisadorlntérprete (BPI), eixo Cohabitar com a Fonte, desenvolvido pela Professora Doutora Graziela Rodrigues. Para tanto, foi realizada uma pesquisa de campo com manifestações localizadas nos municípios de Lagarto e Itabaiana em Sergipe, com aprofundamento na dança do casal de Cangaceiros das Quadrilhas Sergipanas. Durante o projeto, a orientanda frequentou aulas práticas de Dança do Brasil, que aprimoram a Técnica de Dança e a Técnica dos Sentidos dentro do método BPI, bem como fez diários de campo e de dojo para registro das vivências dentro e fora do campo. Em uma segunda etapa, foram realizados laboratórios dentro do método BPI dirigidos pela Orientadora e Professora Doutora Graziela Rodrigues e pela Professora Doutora Larissa Turtelli, objetivando desenvolver a identidade corporal e desta forma alcançar uma síntese corpórea da investigação realizada.

\section{Palavras-chave}

Dança do Brasil, Bailarino-Pesquisador-Interprete, Co-habitar com a Fonte.

\section{Introdução}

O objetivo deste trabalho foi efetuar uma pesquisa corporal fundamentada no Método BPI, priorizando o segundo eixo do método o Cohabitar com a fonte. Neste eixo a intérprete dedicase a uma pesquisa de campo em um segmento social e ou manifestação cultural popular de seu interesse. Neste caso a pesquisadora debruçouse sobre a dança dos cangaceiros realizada dentro das quadrilhas sergipanas, conhecida como Xaxado. A segunda etapa do projeto fundamentouse no estudo da reverberação da experiência em campo no corpo da pesquisadora em seus aspectos mais profundos. O processo criativo se baseia nos conteúdos imagéticos, emocionais, sensitivos e motores que emergem do corpo através da Técnica dos Sentidos do método BPI.

\section{Resultados e Discussão}

A síntese resultante da pesquisa de campo abordam o encontro da pesquisadora com um cotidiano de gerações passadas e familiares desconhecidos, em uma identificação com os festejos, histórias, espaços e trabalhos, ainda preservados. Revelouse para a pesquisadora durante esta pesquisa de campo uma cultura velada até então. A respeito da síntese dos laboratórios práticos, encontrase em percurso a estruturação no corpo da bailarina uma personagem andarilha, que vive por matas fechadas, riachos, estradas de terra batida, festejos e pequenos vilarejos. Flor, como se auto intitula muitas vezes, tem a parte de cima do corpo coberta de plantas, uma saia com pequenos objetos que são lembranças de pessoas e ainda carrega consigo pistolas, garrafas e cestos. Apresenta com freqüência conteúdos emocionais de vaidade, exibicionismo, perda, raiva, fuga, desafio e enfrentamento.

\section{Conclusões}

O método possibilitou a apreensão sensível da pesquisa de campo acompanhada da ampliação e aprofundamento do contato da pesquisadora consigo mesmo, tornando possível uma criação artística que emerge do cerne da intérprete criadora.

\section{Agradecimentos}

À Profa. Dra. Graziela Rodrigues, à Profa. Dra. Larissa Turtelli, à Nara Cálipo e a todo o Grupo de Pesquisa BailarinoPesquisadorIntérprete e Dança do Brasil e ao Departamento de Artes Corporais do Instituto de Artes da Unicamp, que tornaram possível este projeto, e aos financiadores, Pró reitoria de Pesquisa da UNICAMP, $\mathrm{PIBIC}$ e CNPq.

RODRIGUES, Graziela Estela Fonseca. O método BPI (BailarinoPesquisadorIntérprete) e o desenvolvimento da imagem corporal:reflexões que consideram o discurso de bailarinas que vivenciaram um processo criativo baseado neste método. Campinas: [s.n], 2003. 